\title{
Reproductive seasonality of the invasive ascidian Didemnum vexillum in New Zealand and implications for shellfish aquaculture
}

\author{
Lauren M. Fletcher ${ }^{1,2, *}$, Barrie M. Forrest ${ }^{1}{ }^{,}$Javier Atalah $^{1}{ }^{1}$ James J. Bell $^{2}$ \\ ${ }^{1}$ Cawthron Institute, Private Bag 2, Nelson 7010, New Zealand \\ ${ }^{2}$ School of Biological Sciences, Victoria University of Wellington, PO Box 600, Wellington 6140, New Zealand
}

\begin{abstract}
The global spread of invasive fouling species poses a significant barrier to the development of shellfish aquaculture, which has led to a need to understand the biological characteristics of fouling species that underpin management. One such fouling species, the colonial ascidian Didemnum vexillum, has become a very successful invader in temperate marine communities worldwide, and is proving problematic in a number of aquaculture regions. To evaluate the scope for managing risks to shellfish aquaculture around seasonal reproductive patterns, we assessed recruitment and larval development of $D$. vexillum in relation to water temperature, over a 20 mo period at 2 locations in central New Zealand. Our findings indicate that the reproductive season for $D$. vexillum in New Zealand is considerably longer than comparable northern-hemisphere populations (at least 9 mo of the year compared with 3 to 5 mo in the USA). Reproductive patterns were strongly correlated with water temperature, with a 3 mo period during the winter months (surface water temperature $<12^{\circ} \mathrm{C}$ ) when larval recruitment was not detected at our study sites. However, during that period, late-stage larvae were often present in tissue sections, suggesting that the species has the potential to recruit year-round, albeit at very low levels during winter. Information on the duration of the reproductive season as well as critical temperature thresholds for spawning will enable more effective risk management in relation to aquaculture industry practices (e.g. timing of seed-stock deployment), as well as assist in the wider management of this species.
\end{abstract}

KEY WORDS: Biofouling · Non-indigenous species · Reproductive patterns · Temporal variation · Larval settlement $\cdot$ Recruitment $\cdot$ Tunicate $\cdot$ New Zealand

\section{INTRODUCTION}

The global spread of invasive species poses a significant practical and economic barrier to the development of shellfish aquaculture (McKindsey et al. 2007). Biofouling in particular poses a considerable threat to this industry, as fouling organisms are often strong spatial competitors that are able to reach a very high density or biomass in relatively short time frames (Dealteris et al. 2004, Blum et al. 2007, Vance

*Email: lauren.fletcher@cawthron.org.nz et al. 2009). Ascidians are among the most prolific and devastating biofoulers to shellfish aquaculture operations globally (Lambert 2007, Valentine et al. 2007b, Ramsay et al. 2008, Daigle \& Herbinger 2009, Adams et al. 2011). Impacts caused by ascidian fouling include increased costs of production and processing, as well as negative effects on growth rates and meat yields of cultured species due to competition for space and food resources (reviewed by Fitridge et al. 2012). The proliferation of fouling

(C) The authors 2013. Open Access under Creative Commons by Attribution Licence. Use, distribution and reproduction are unrestricted. Authors and original publication must be credited. 
organisms and their associated impacts on the aquaculture industry has led to an increased demand for tools to mitigate effects, and a need to understand the biological characteristics of fouling species that underpin management.

Knowledge of the seasonal development and recruitment success of marine fouling organisms is of particular importance in formulating effective management strategies (Ramsay et al. 2009). For example, understanding seasonal recruitment variation and its environmental drivers will help to define circumstances (e.g. time periods) when fouling of seedstock, crop or aquaculture structures may be problematic or, alternatively, when it may be of little consequence for industry operations. The reproductive seasonality of ascidians can vary widely (e.g. Turon 1988, 1992) and is poorly understood for many species (Perez-Portela et al. 2007), but it is apparent that water temperature is a dominant controlling factor (reviewed by Bates 2005, C. C. Lambert 2005, G. Lambert 2005). For temperate ascidian species, spawning typically occurs during the summer months (G. Lambert 2005), with a subsequent decline, and in some instances a temporary halt, in growth and reproduction over the colder months (Coma et al. 2000). By contrast, ascidian populations in warmer waters, such as many tropical regions, have been shown to release gametes continuously year-round (Goodbody 1961, Van Duyl et al. 1981, Stoner 1990).

The reproductive seasonality of the colonial ascidian Didemnum vexillum (Kott 2002) is of increasing international interest, as this species has become a very successful invader in temperate marine communities worldwide; its alien range includes both coasts of North America, northwestern Europe, the UK, Ireland and New Zealand (Stefaniak et al. 2012). D. vexillum colonies are capable of rapid growth and expansion through both sexual and asexual reproduction, and are able to quickly foul large areas of any suitable substratum. In New Zealand, the rapid growth and high biomass of $D$. vexillum on subtidal mussel farms can lead to the destabilisation of crops and added pressure on equipment, which has in some instances led to substantial management costs (e.g. Coutts \& Forrest 2007, Pannell \& Coutts 2007). Understanding the species' reproductive seasonality and recruitment patterns, and the utility of seawater temperature as an indicator of recruitment potential, is integral to such management efforts.

The influence of seawater temperature on reproductive patterns in Didemnum vexillum has previously been inferred from observations made in a number of studies from both the northeast and west coasts of the USA. The length of the reproductive season has been shown to vary, from 3.5 to $5 \mathrm{mo}$, depending on local conditions (Auker 2006, Osman \& Whitlatch 2007, Auker \& Oviatt 2008, Valentine et al. 2009, Sorte \& Stachowicz 2011). D. vexillum embryos are brooded within the tunic of the colony and are believed to take several weeks to fully develop into 'tadpole' larvae about $1.4 \mathrm{~mm}$ in length (Lambert 2009). Once mature, larvae are released from the parent colony via shared excurrent siphons (see Kott 2002 for a description of colony morphology). Spawning is believed to be dependent on seawater temperatures achieving a critical threshold, with larval recruitment thought to occur when sea surface temperatures exceed $14^{\circ} \mathrm{C}$ (Valentine et al. 2009). Recruitment of $D$. vexillum is believed to be restricted by very low water temperatures in some areas, with colonies generally undergoing periods of degeneration during colder winter months (Valentine et al. 2007a). Despite progress towards understanding the importance of temperature on reproductive seasonality, it remains unclear whether temperature-related recruitment patterns are consistent among different geographic locations. Moreover, it is unclear whether temperature-related changes within a location are consistent and predictable over time.

The aim of the present study was to better elucidate the reproductive seasonality of Didemnum vexillum in relation to seasonal changes in seawater temperature. We describe patterns of field recruitment and tissue reproductive state, and develop statistical models to predict critical temperature thresholds for the onset and cessation of $D$. vexillum recruitment. We also consider the relative sensitivity, utility and practicality of directly measuring recruitment in the field compared with inferring recruitment potential based on the reproductive maturity of $D$. vexillum tissue samples. Such knowledge will assist the aquaculture industry, as well as other stakeholders, in monitoring risk and developing appropriate management responses for this species.

\section{MATERIALS AND METHODS}

\section{Recruitment studies}

The temporal recruitment patterns of Didemnum vexillum larvae were investigated in field studies at 2 sites (Nelson, NN; Ruakaka Bay, RK) over a 20 mo period between 7 November 2007 and 29 July 2009. Sampling at the RK study site was carried out on a 
large marine farm located in Queen Charlotte Sound (ca. $41^{\circ} 13^{\prime} \mathrm{S}, 174^{\circ} 7^{\prime} \mathrm{E}$ ), within New Zealand's Marlborough Sounds region, whereas the NN site was situated approximately $80 \mathrm{~km}$ west (ca. $41^{\circ} 15.4^{\prime} \mathrm{S}$, $\left.173^{\circ} 16.6^{\prime} \mathrm{E}\right)$ within the commercial port at Nelson (Fig. 1). Sites were within or adjacent to important shellfish aquaculture zones and had substantial populations of $D$. vexillum present; however, the population at RK was considerably larger (ca. 30 tonnes wet weight) than the NN population (ca. 2 tonnes wet weight) at the time of sampling. Source population weight estimates were calculated based on a preliminary survey of $D$. vexillum biomass present on the predominant substrata available at each location (e.g. RK: steel pontoon, exterior netting; NN: wharf piles, marina berths) (L. Fletcher unpubl. data). The RK site was in relatively deep water ( 30 m depth), while the NN site was in a shallow ( $\sim \mathrm{m}$ depth), predominantly estuarine environment with a large tidal exchange. We expected that differences between sites in terms of their environmental characteristics and the spatial distribution of $D$. vexillum would influence the magnitude of recruitment; however, in this study we were primarily interested in the seasonal patterns in the occurrence of recruitment in relation to seawater temperature.

To measure Didemnum vexillum recruitment, 5 arrays, each with 3 settlement plates attached, were deployed from floating structures at each site $(\mathrm{n}=15$ per sampling period), with arrays spaced approximately $5 \mathrm{~m}$ apart. The settlement plates were made from roughened black Perspex $(20 \times 20 \mathrm{~cm})$ and were

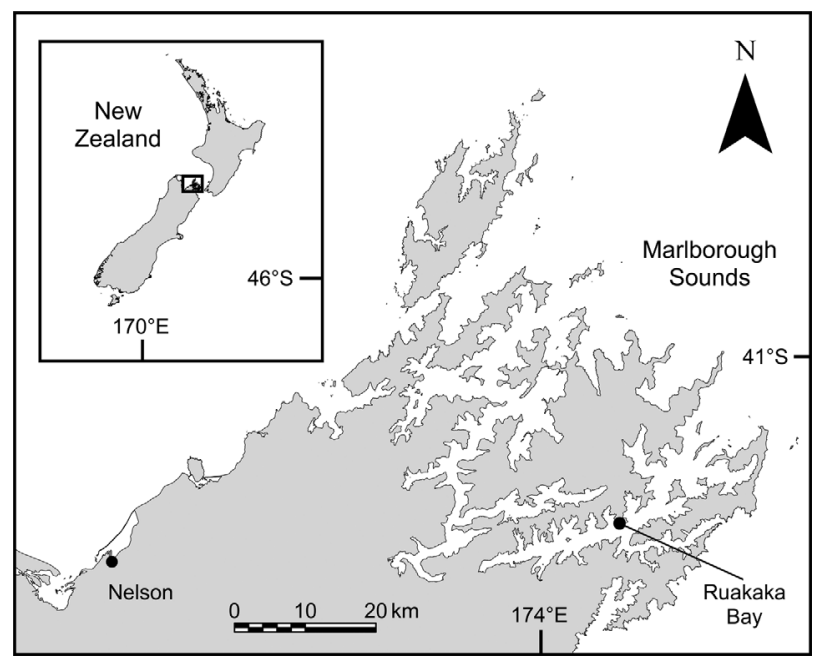

Fig. 1. Study sites within the Nelson and Marlborough Sounds regions. The 2 study sites used in the Didemnum vexillum recruitment field study, Nelson (NN) and Ruakaka Bay (RK), are marked positioned horizontally within each array and configured to ensure they remained at a constant depth $(0.5$ to $1.5 \mathrm{~m}$ ) with respect to the water surface. The plates were retrieved and replaced weekly from November 2007 through to the beginning of May 2008. Due to logistic constraints, the sampling period was subsequently changed to fortnightly from 7 May 2008 until the end of sampling in July 2009. At the end of each sampling period (week or fortnight), the arrays were retrieved and immediately returned to the laboratory for analysis. Using a dissecting microscope, the numbers of $D$. vexillum recruits were counted on the downward-facing surface of each plate, reflecting the orientation where maximum recruitment occurs (Valentine et al. 2009). A $2 \mathrm{~cm}$ buffer zone around the edge of each plate was excluded to account for edge effects (Hurlbert 1984); hence data were recorded as counts of individuals recruiting to the central $16 \times$ $16 \mathrm{~cm}\left(256 \mathrm{~cm}^{2}\right)$ of each plate. The term recruitment is used here as a measure of the number of newly settled individuals that survive between settlement and the time a census is taken (Keough \& Downes 1982).

\section{Tissue section analysis}

At the time of the recruitment study, we also conducted tissue section analysis of Didemnum vexillum for different larval developmental life-stages. Compared with recruitment studies, tissue analysis is more straightforward and gives immediate results. Our goal was to evaluate whether tissue analysis could provide a sensitive indicator of the potential for larval recruitment, which would serve as a useful proxy variable for monitoring purposes. Due to logistic constraints, we undertook this study for the RK site only. From that site, 5 lobe-shaped D. vexillum colony tissue samples $\left(<30 \mathrm{~cm}^{2}\right.$ area, $\left.\sim 50 \mathrm{~g}\right)$ were collected every fortnight over the 20 mo sampling period. Lobe-shaped colonies were preferred as they generally had less detritus and epibionts associated with them, and could be sampled without damaging the embryos. As embryos are brooded within the tunic beneath the zooids in Didemnum species, removal of encrusting or 2-dimensional colonies from the substratum can damage them. Samples were collected from distinct colonies spaced $>5 \mathrm{~m}$ apart to ensure independence. Each sample was immediately preserved in fixative ( $70 \%$ ethanol, $5 \%$ glyoxal) and transported back to the laboratory.

In the laboratory, 10 cross-sections were excised from each sample, with a thickness of $1 \mathrm{~mm}$ that ensured the central test region (where the embryos 


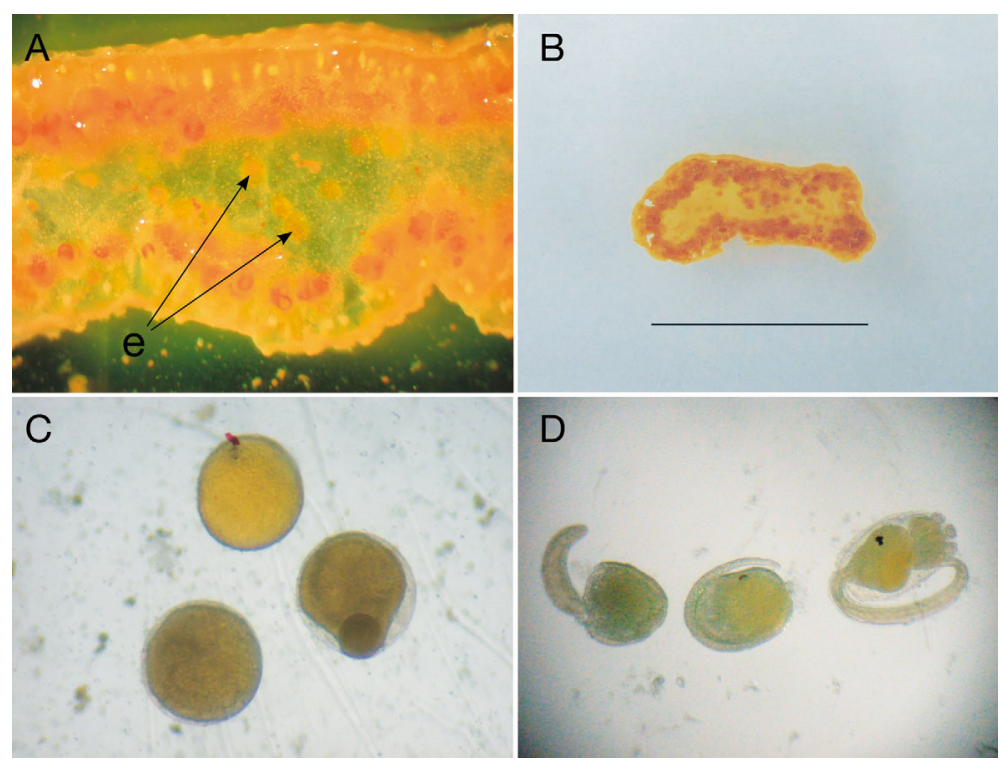

Fig. 2. Didemnum vexillum. Colony tissue section photographs: (A) close-up of a tendril cross-section highlighting individual zooids surrounding colony perimeter and brooded embryos (e) in the central test region; (B) illustration tissue section photograph, scale bar $=10 \mathrm{~mm}$; (C) D. vexillum eggs; and (D) development stages of $D$. vexillum larvae: early tail bud, late tail bud and mature larvae (from left to right). Photos A, C and D courtesy of A. Coutts

ence of early tail bud larvae, (4) presence of late tail bud larvae, and (5) presence of mature larvae. A fortnightly maturity index (MI) was calculated using the formula of Yoshida (1952):

$$
\mathrm{MI}=\frac{\Sigma n F}{N}
$$

where $F$ is the reproductive stage ( 1 to 5 in Didemnum vexillum), $n$ is the number of sections in stage $F$, and $N$ is the total number of sections examined.

\section{Environmental data}

Water temperature was measured hourly for the duration of the study using a TidbiT v2 Temperature Logger positioned at $1 \mathrm{~m}$ depth at each site. Water temperature data are reported as either weekly or fortnightly averages depending on the sampling period. Maximum and minimum temperatures during each sampling period and temperature change

are brooded) remained intact (Fig. 2A,B). Sections were taken from different parts of the colony to ensure a range of tissue was sampled. In total, 45 sampling dates were analysed, with 50 sections examined for each date (i.e. 5 samples each with 10 subsamples per occasion), yielding a total of 2250 cross-sections. Each section was mounted on a glass slide and examined for reproductive condition under a dissecting microscope. All embryos present within the central test region were assigned to 1 of 4 reproductive stages (e.g. Fig. 2C,D): egg; early tail bud (small tail budding off from main body, no eyespot); late tail bud (lengthening of tail, formation of dark eyespot, possible presence of papillae); and mature larvae (3 papillae used for attachment to substratum, defined eyespot visible), and counts of each stage recorded. A digital photo was taken of each section with the camera positioned at a standard distance from the slide, and image analysis (ImageJ; Abramoff et al. 2004) was used to calculate its total cross-sectional area. The reproductive stage counts were then standardised to $1 \mathrm{~cm}^{2}$ of colony tissue, to allow comparison between sampling dates and prevent bias due to differences in tissue section size (and thus capacity to produce and brood embryos). Sections were also scored to 1 of the following 5 categories according to the highest reproductive stage present: (1) no embryos present, (2) presence of eggs, (3) pres- between periods were also calculated. In addition, day length data for both sites were obtained from the US Naval Meteorology and Oceanography Command (USNO 2012).

\section{Statistical analyses}

The recruitment count data contained a disproportionately high number of zero values (448 of the 1710 observations $=26.2 \%$ ), as well as overdispersion (variance higher than the mean) in the non-zero count data. As such, recruitment data at both sites were analysed using a zero-inflated negative binomial (ZINB) regression model, which assumes that the population consists of 2 different types of observation: zero counts, and non-zero counts, which are modelled using a negative binomial distribution (Zuur et al. 2009). A range of explanatory variables were initially examined (temperature, day length, plate exposure time, Julian day, month, season, year, site), and highly co-linear variables were omitted. The Akaike information criterion (AIC) was used for model selection; the final model was validated through inspection of the residuals, and consisted of recruitment counts as the dependent variable, with temperature, site (NN or RK), and year (Year 1 or Year 2) as predictor variables. 
Critical temperatures associated with the onset of Didemnum vexillum recruitment, as well as the subsequent cessation as water temperatures declined, were also investigated. Data were split into 8 sections based on site, year and pre-summer or post-summer phase. The pre-summer phase was represented by the data sub-group from the onset of recruitment to its summer maximum, whereas the post-summer phase extended from this summer peak to the midwinter cessation of recruitment. The need to analyse these 2 different phases separately arose from their distinctively different recruitment versus temperature responses. For each site, season and pre- or postsummer combination, either linear or negative binomial regression models were fitted to the data depending on which best described the dataset structure, as determined through AIC and residual analysis. These models were used to calculate the water temperatures at which the predicted recruitment was $<1$ (reflecting the presence of a single recruit on 1 settlement plate). A regression model was not fitted for the pre-summer phase at NN during Year 1, as recruitment was already well underway when sampling was started at that site.

Differences in the abundances of larval development stages were tested using a distance-based permutational analysis (PERMANOVA; Anderson 2001) based on Bray-Curtis similarity matrices of squareroot-transformed data. The experimental design comprised 2 factors: Year (random with 2 levels) and Season (with 4 levels nested in Year), with water temperature included as a covariate. Fortnightly sampling events were assigned to seasons based on the meteorological calendar, and each contained data from 3 complete months. Each term in the analyses was tested using 9999 random permutations of the appropriate units (Anderson 2001). Similarity percentage analysis (SIMPER; Clarke 1993) was used to identify the percentage contribution of each stage to observed differences between factors.

The fortnightly MI was related to fortnightly average water temperatures using the Pearson product-moment correlation coefficient. Additionally, cross-correlation analyses were used to compare the temporal trend of MI with recruitment levels measured in Didemnum vexillum over the course of the study. In cross-correlation, 2 series of data are lagged with respect to one another (time lags were in fortnights), and the usual Pearson correlation coefficient is computed on the transformed series. Correlations at time lag $t$ measure relationships of the values of the first series with values of the second series $t$ fortnights earlier (negative lags) or later (positive lags). Multivariate analyses were performed using the software PRIMER 6 and PERMANOVA (Clarke \& Gorley 2006, Anderson \& Gorley 2007). All other analyses were carried out using software package $\mathrm{R}$ version 2.13.2 (R Development Core Team 2011), as implemented in the zeroinfl and MASS libraries.

\section{RESULTS}

\section{Environmental data}

The average water temperature data showed a regular cyclic annual pattern, although seasonal ranges differed appreciably between the sites (Fig. 3). Water temperatures at NN showed a wider seasonal range, with temperatures higher in the austral summer and lower over the winter months than at RK. The lowest average temperature at NN was recorded during the last month of the study (16 to 29 July 2009; min. $9.1^{\circ} \mathrm{C}_{i}$ Fig. 3), while the lowest at RK was recorded during the preceding fortnight (2 to 15 July 2009; min. $10.4^{\circ} \mathrm{C}_{i}$ Fig. 3). The highest average water temperatures at both sites were recorded at the beginning of February 2008, with temperatures reaching a maximum of $22.7^{\circ} \mathrm{C}$ at $\mathrm{NN}$ and $18.7^{\circ} \mathrm{C}$ at RK (30 January to 6 February 2008; Fig. 3). Daylight hours followed a regular cyclic annual pattern; the shortest days were recorded in mid-June each year (9:11 h; Fig. 3), increasing to a maximum length during late December each year (15:09 h; Fig. 3). Generally, the

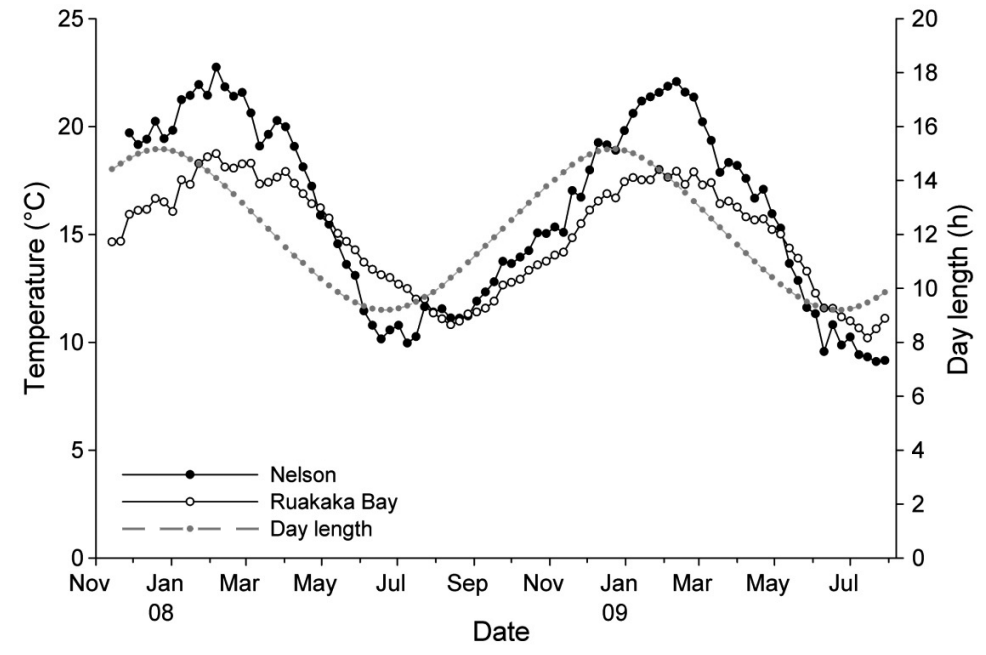

Fig. 3. Weekly average sea surface temperature profiles from study sites at Nelson and Ruakaka Bay, and recorded day length in Nelson, New Zealand 
change in seawater temperature lagged 1 to 2 mo behind the change in day length.

\section{Recruitment patterns in relation to seawater temperature}

A well-defined seasonal pattern of recruitment was evident for Didemnum vexillum over the course of the study. Recruitment occurred at both sites over 2 distinct reproductive seasons: November 2007 to July 2008 (Year 1), and October 2008 to July 2009 (Year 2). At NN in Year 1, recruits were detected from commencement of sampling (28 November 2007), when the water temperature had already reached a weekly average of $19.7^{\circ} \mathrm{C}$. In Year 2, recruitment commenced on 5 November 2008, when the average water temperature for the previous week was $15.2^{\circ} \mathrm{C}$ (Fig. 4A). Recruits were first detected in Year 1 at RK on 28 November 2007, when the average water temperature for the preceding week was $15.9^{\circ} \mathrm{C}$. The Year 2 recruitment at RK commenced approximately a month earlier on 22 October 2008, when the average water temperature for the previous fortnight was $13.6^{\circ} \mathrm{C}$ (Fig. 4B). Recruitment levels at RK were considerably higher than NN over the entire sampling period. The highest recruitment recorded at NN was in Year 2 on 28 January 2009, with an average of $125.1 \pm 2.6$ (mean $\pm \mathrm{SE}$ ) recruits plate ${ }^{-1}$ (Fig. 4A). The highest recruitment recorded at RK coincided with this peak at NN (28 January 2009), with an average of $431.9 \pm 59.3$ recruits plate ${ }^{-1}$ (Fig. 4B). At RK, the peak in $D$. vexillum recruitment was concurrent with the peak water temperature in both years (Fig. 4B). In contrast, peak recruitment at NN occurred prior to the peaks in water temperature across both years $(3$ and 2 wk prior for Years 1 and 2, respectively; Fig. 4A).
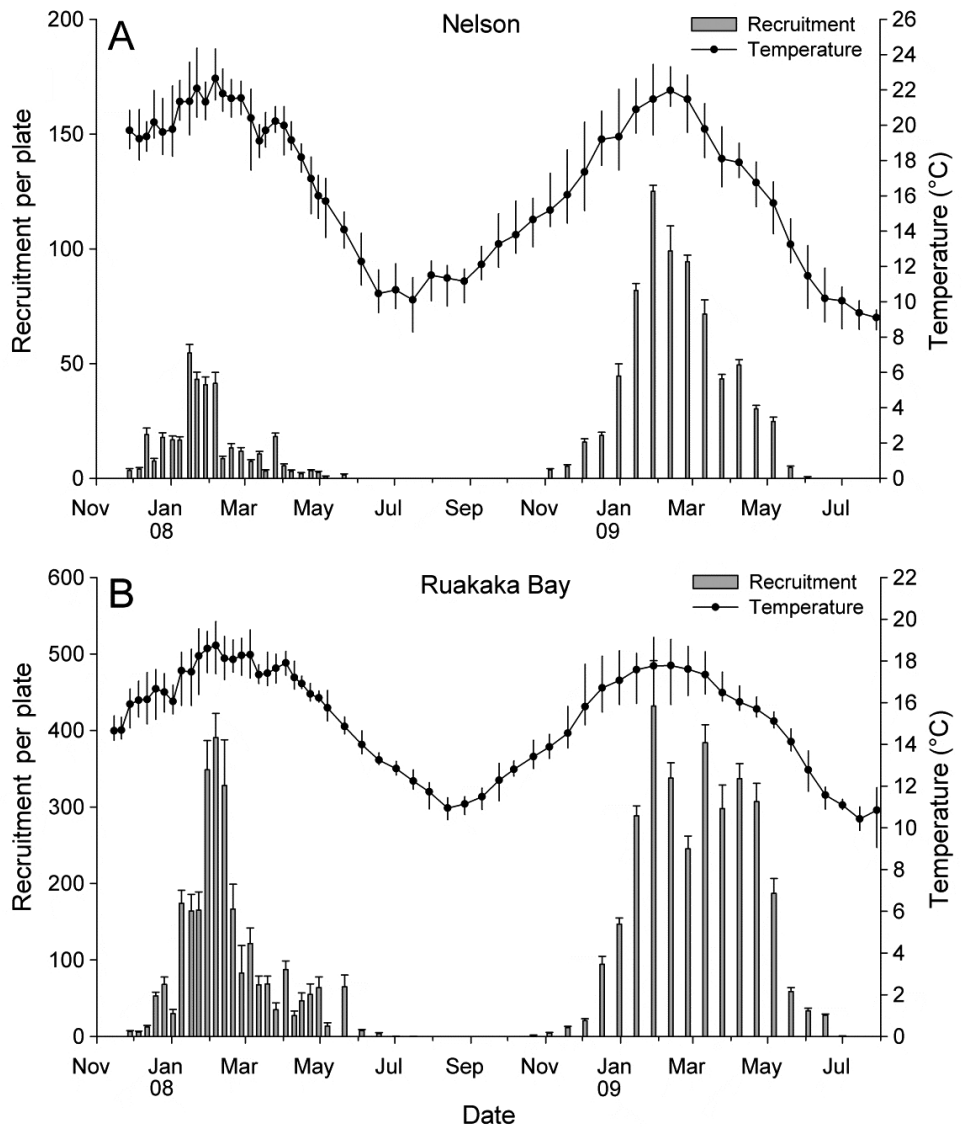

Fig. 4. Didemnum vexillum. Mean number $\left( \pm \mathrm{SE}_{\mathrm{i}} \mathrm{n}=15\right.$, except for Ruakaka Bay on 21 May 2008, which was $\mathrm{n}=12$ ) of recruits per $256 \mathrm{~cm}^{2}$ and water temperature profile at both the (A) Nelson and (B) Ruakaka Bay sites. Sampling frequency changed from weekly to fortnightly on 21 May 2008. Error bars on the temperature profile represent the range of water temperatures (maximum and minimum values) recorded during that sampling period. Note the differences in scale on both $y$-axes
Higher water temperatures were associated with higher levels of recruitment (Fig. 5), and the ZINB regression model predicting Didemnum vexillum recruitment levels from average water temperature, location and reproductive season was highly significant (chi-squared test, $\chi_{6}^{2}=2547.7, \mathrm{p}<$ 0.001). All 3 explanatory variables included were statistically significant in both parts of the model ( $p<0.05$; Table 1$)$. Based on the negative binominal model estimates, the expected number of recruits per plate was predicted to be $1.64\left(=\exp ^{0.495}\right)$ times higher following a $1^{\circ}$ rise in the water temperature, while holding all other variables in the model constant. The expected recruitment at RK was $20.63\left(=\exp ^{3.027}\right)$ times higher than the expected recruitment at NN, assuming constant water temperatures and within the same reproductive season (Year). Similarly, the expected recruitment in Year 2 was $4.53\left(=\exp ^{1.510}\right)$ times higher than the expected recruitment in Year 1, assuming constant water temperatures and location (Table 1).

The regression curves fitted to pre- and post-summer phases accurately modelled the recruitment data at both sites and years, evident from the relatively narrow range (i.e. $95 \%$ confidence interval) of predicted recruitment levels with changes in water temperature (Fig. 6). Water temperatures where predicted recruitment levels were $<1$ were higher when modelling the onset 

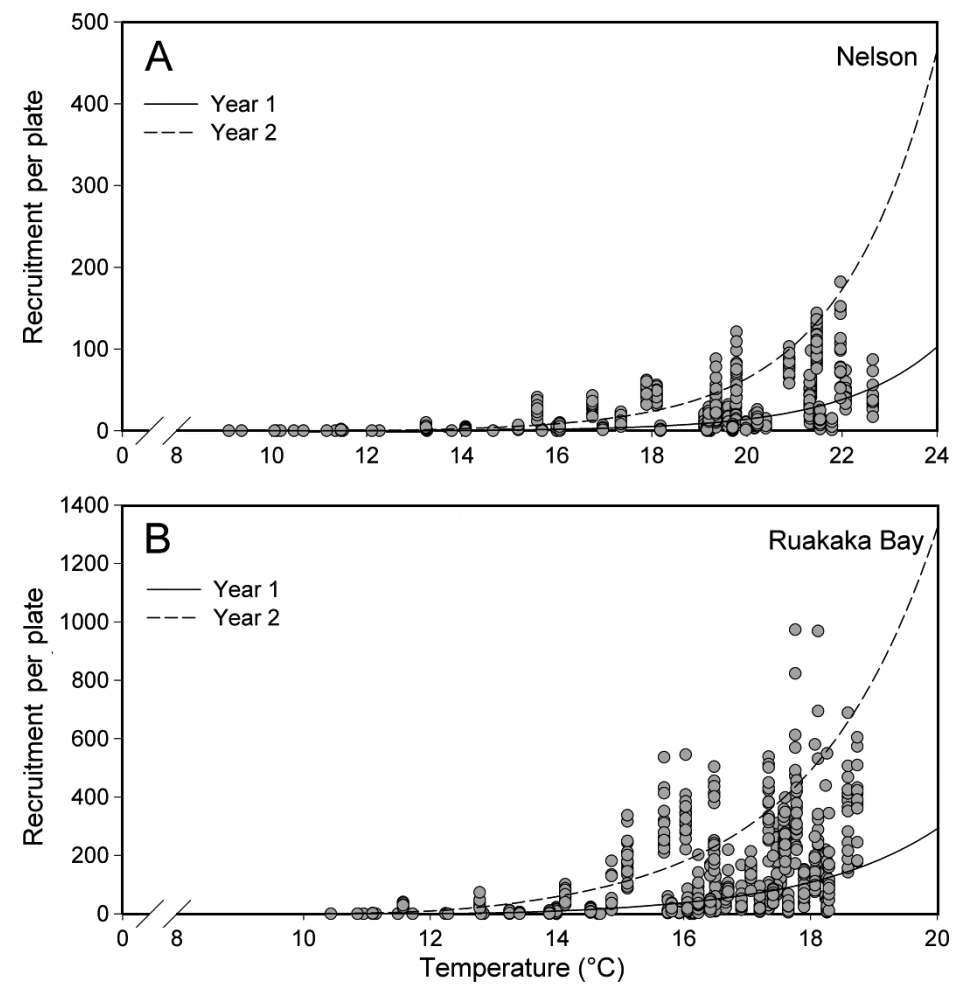

Fig. 5. Didemnum vexillum. Relationship between $D$. vexillum recruitment and water temperature at both the (A) Nelson and (B) Ruakaka Bay sites during the 2007-08 and 2008-09 reproductive seasons (Year 1 and Year 2, respectively). Note the difference in scale on both the $x$ - and $y$-axes

of recruitment, as opposed to the cessation, in all instances. Recruitment was predicted to begin at $\mathrm{NN}$ when water temperatures reached $13.4 \pm 0.4^{\circ} \mathrm{C}$ (Fig. 6A). This was similar to RK, where the critical thresholds for recruitment were predicted to be $13.9 \pm 0.2^{\circ} \mathrm{C}$ and $12.8 \pm 0.2^{\circ} \mathrm{C}$ for Year 1 and Year 2, respectively (Fig. 6B). By contrast, there was greater site and year variation in the predicted temperature thresholds for the cessation of recruitment at the end of the post-summer phase. The threshold water tem- peratures for the post-summer phase were $14.9 \pm 0.5^{\circ} \mathrm{C}$ and $12.0 \pm 0.6^{\circ} \mathrm{C}$ at $\mathrm{NN}$ for Year 1 and Year 2, respectively (Fig. 6A). Recruitment was predicted to extend to even lower temperature at $\mathrm{RK}$, with threshold water temperatures of $11.5 \pm 0.1^{\circ} \mathrm{C}$ and $11.1 \pm$ $0.5^{\circ} \mathrm{C}$ in Year 1 and Year 2, respectively (Fig. $6 \mathrm{~B})$. Despite the difference between NN and $\mathrm{RK}$, it is evident that within each location, the water temperature threshold in Year 2 was cooler than in Year 1.

\section{Tissue section analyses}

A distinct overall pattern of seasonality in tissue reproductive state was shown for all 4 reproductive stages over the 20 mo of study. Abundances of the 4 larval development stages (Fig. 7A) and MI values (Fig. 7B) were at their lowest levels during the winter months (July and August) each year, and peaked in summer. Despite this general pattern, the different metrics showed marked variation on shorter time-scales. PERMANOVA revealed highly significant temperature and season (nested in year) effects on the proportion of different larval stages present $(\mathrm{p}<0.01$; Table 2$)$. No significant differences were found between the 2 years $(p=$ 0.761; Table 2).

The SIMPER procedure revealed that significant differences between seasons were primarily due to fluctuations in the proportion of eggs (SIMPER \% contribution ranged from 83.6 to $92.1 \%$ ). The average abundance of eggs was high during summer $(22.2 \pm 2.2 \mathrm{SE})$, autumn $(29.9 \pm 3.6 \mathrm{SE})$ and spring $(27.9 \pm 4.2 \mathrm{SE})$, with a considerable drop in average abundance over the winter season $(7.6 \pm 1.9 \mathrm{SE})$.

Table 1. Didemnum vexillum. Maximum likelihood parameter estimates of the multiple zero-inflated negative binomial (ZINB) regression model fitted to the recruitment count data. Reference factor levels and the dispersion parameter (log [theta]) are indicated. Significant values $(p<0.05)$ are indicated in bold

\begin{tabular}{|c|c|c|c|c|c|c|c|}
\hline \multirow{2}{*}{\multicolumn{2}{|c|}{ Parameter }} & \multicolumn{3}{|c|}{ Negative binomial part } & \multicolumn{3}{|c|}{ Zero-inflated part } \\
\hline & & Estimate (SE) & $z$ & $\mathrm{p}$ & Estimate (SE) & $z$ & $\mathrm{p}$ \\
\hline Inter & & $-7.248(0.289)$ & -25.063 & $<0.001$ & $16.783(1.190)$ & 14.099 & $<0.001$ \\
\hline Temp & & $0.495(0.014)$ & 34.414 & $<0.001$ & $-1.179(0.078)$ & -15.205 & $<0.001$ \\
\hline \multirow[t]{2}{*}{ Site } & Nelson & Reference & & & Reference & & \\
\hline & Ruakaka Bay & $3.027(0.063)$ & 48.410 & $<0.001$ & $-0.800(0.326)$ & -2.450 & 0.014 \\
\hline \multirow[t]{2}{*}{ Year } & Year 1 & Reference & & & Reference & & \\
\hline & Year 2 & $1.510(0.058)$ & 26.234 & $<0.001$ & $-1.369(0.276)$ & -4.961 & $<0.001$ \\
\hline \multicolumn{2}{|c|}{ Log (theta) } & $0.302(0.041)$ & 7.335 & $<0.001$ & & & \\
\hline
\end{tabular}



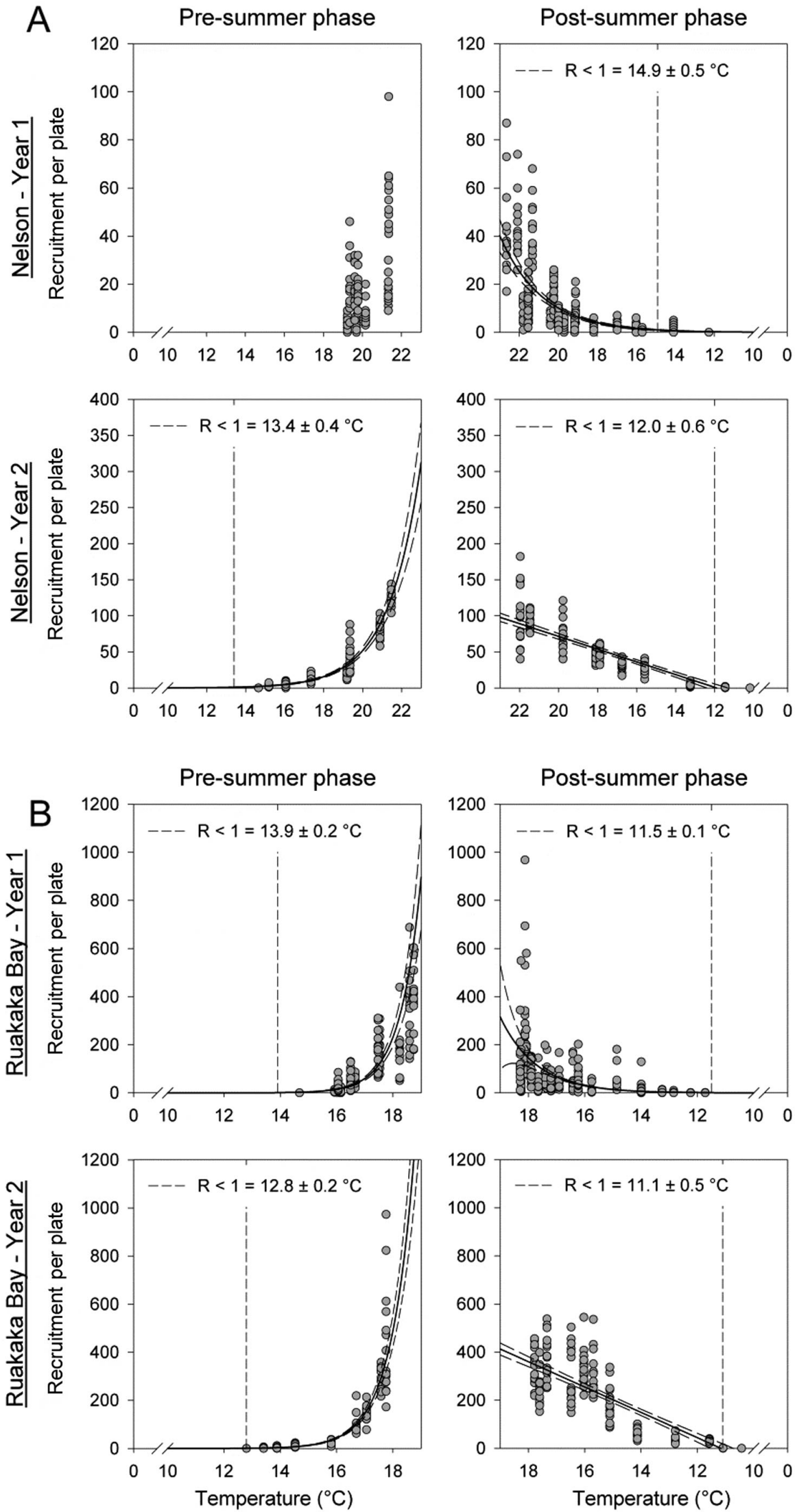

Fig. 6. Didemnum vexillum. Predicted $D$. vexillum recruitment with varying water temperature at both the (A) Nelson and (B) Ruakaka Bay sites. Data were split into 8 sections based on site, year and pre-summer or post-summer phase. The pre-summer phase was represented by the data sub-group from the onset of recruitment to its summer maximum, whereas the post-summer phase extended from this summer peak to the mid-winter cessation of recruitment. Solid lines represent regression models fitted to the data to predict recruitment at increasing or decreasing water temperatures. Dashed lines represent $95 \%$ confidence intervals of the recruitment levels and were derived from the standard error of the estimated parameters. Water temperatures where the predicted recruitment is less than $1(\mathrm{R}<1)$ are indicated where possible (vertical dashed line). Note the difference in scale on the $y$-axis 
Accordingly, MI values also exhibited noticeable decreases during late May to early July each year, although there were also distinct short-term declines during the relatively consistent summer peak of recruitment (compare Figs. 4B \& 7B). Nonetheless, there was a significant positive correlation between fortnightly $\mathrm{MI}$ and water temperature during the course of the study $(r=0.7347$, df $=43, p<0.001)$. Comparing the time course of MI values to that of larval recruitment through cross-correlation analysis revealed a cyclic annual pattern over the course of both variables (Fig. 8A). The maximum correlation value was found at time lag +1 , indicating that peaks in tissue MI values preceded, by 2 to $4 \mathrm{wk}$, the periods of highest recruitment.
Table 2. Didemnum vexillum. Results of PERMANOVA testing for temporal differences in the abundances of larval development stages at scales of season and year, and with water temperature as a covariate. Analyses based on BrayCurtis similarity matrices from the square-root-transformed data. Each term was tested using 9999 random permutations of appropriate units. Estimates of multivariate variation are given for each temporal scale. Significant values $(p<0.05)$ are indicated in bold

\begin{tabular}{|lrrrrr|}
\hline Source & df & \multicolumn{1}{c|}{ SS } & MS & Pseudo- $F$ & p (perm) \\
\hline Temperature & 1 & 8621.20 & 8621.20 & 10.494 & $\mathbf{0 . 0 0 2}$ \\
Year & 1 & 463.78 & 463.78 & 0.503 & 0.761 \\
Season (Year) & 5 & 4039.00 & 807.81 & 4.294 & $<\mathbf{0 . 0 0 1}$ \\
Residual & 36 & 6773.20 & 188.14 & & \\
Total & 43 & 19897.00 & & & \\
\hline
\end{tabular}

Fig. 7. Didemnum vexillum. (A) Reproductive cycle inferred from counts of the 4 different reproductive stages indicated. Tissue sections were taken from colony samples collected fortnightly from Ruakaka Bay between 21 November 2007 and 29 July 2009 ( $\mathrm{n}=50$ per sampling date). (B) Maturity index of colony samples collected fortnightly from Ruakaka Bay between 21 November 2007 and 29 July 2009 ( $\mathrm{n}=50$ per sampling date). Average water temperature values during the period are indicated
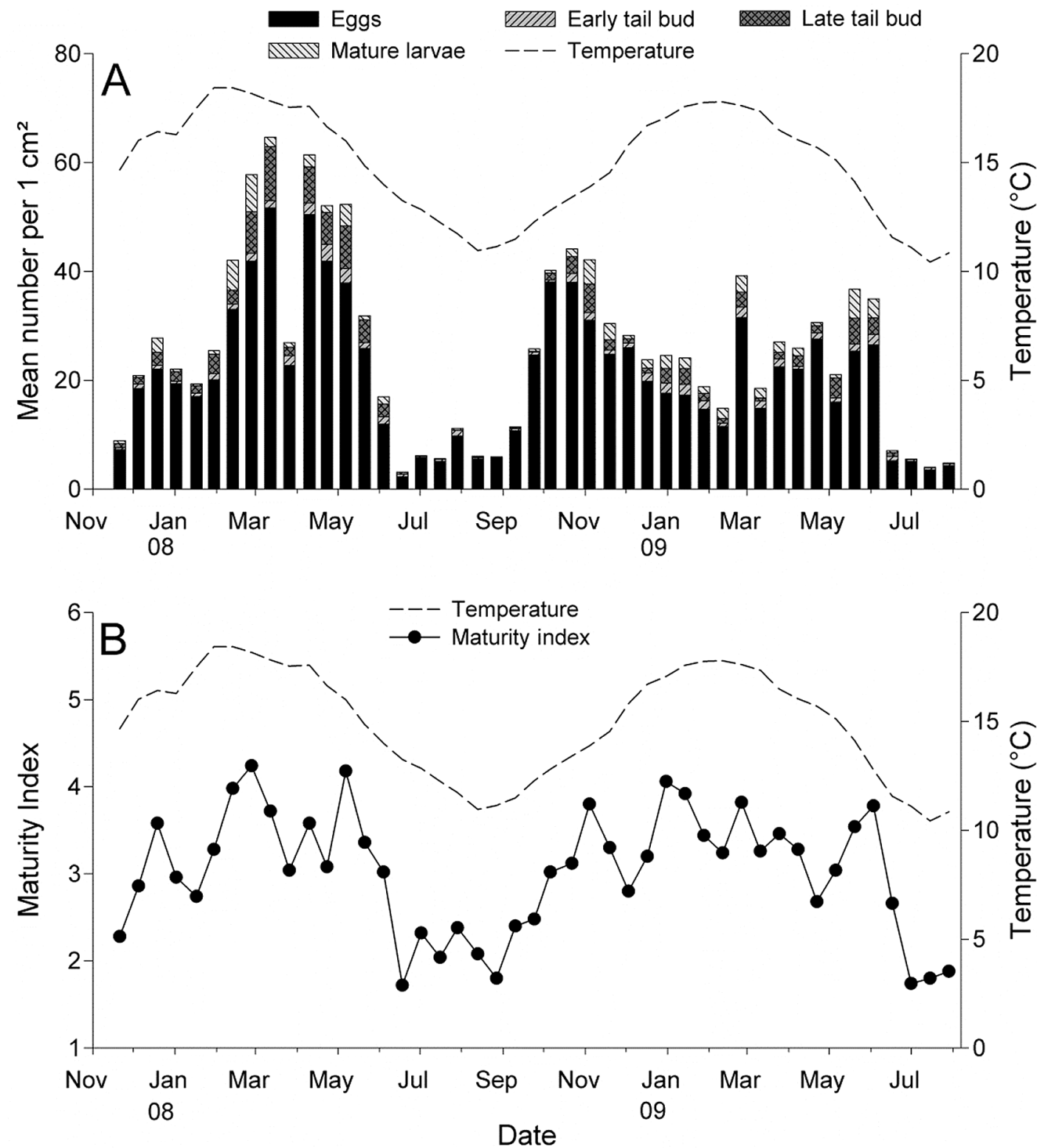
Examination of patterns in the seasonal presence/ absence of the different reproductive stages reveals important patterns that are less obvious in the temporal variability of the count data (Fig. 8B). It is evident that early reproductive stages (eggs, early tail bud, and late tail bud) are present year-round. Mature larvae were detected on $90 \%$ of sampling dates, being sporadically absent during winter months. However, there was no extended period of larval absence. By contrast, recruits were detected on settlement plates at RK on $80 \%$ of sampling events, with a distinct and continuous winter period of some 3 mo without any being recorded (Fig. 8B).
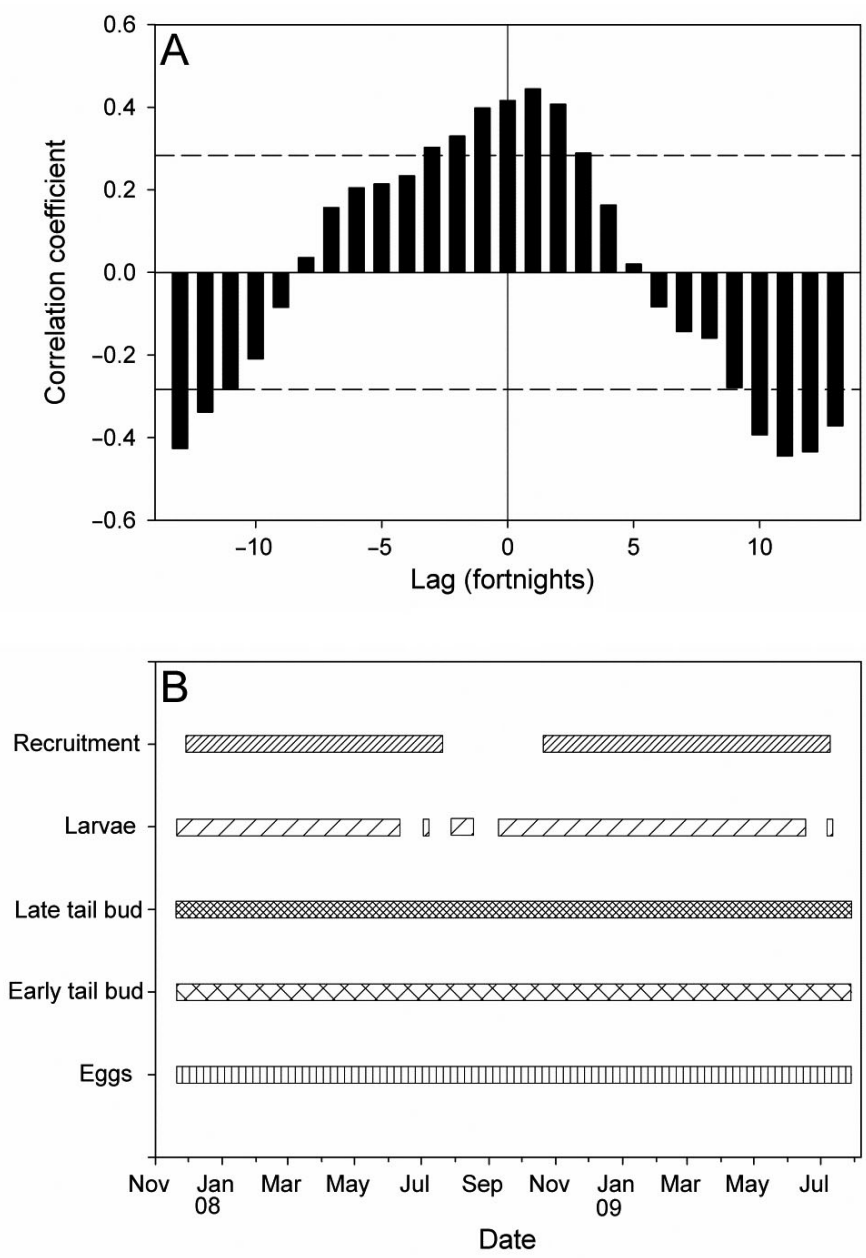

Fig. 8. Didemnum vexillum. (A) Results of the cross-correlation analysis of maturity index (MI) versus larval recruitment for the corresponding sampling period. Data series were lagged with respect to one another (time lags = fortnights), and the Pearson correlation coefficient computed for each transformed series. Dashed lines represent 95\% confidence intervals of the correlation coefficient. (B) Patterns in the seasonal occurrence of larval recruitment as well as the presence/absence of the different reproductive stages

\section{DISCUSSION}

\section{Temporal variation in recruitment at study sites}

The Didemnum vexillum populations at our study sites showed clear seasonality in their reproductive cycles, with recruitment occurring from late spring right through to mid-winter each year. This pattern of reproductive seasonality and peaks in larval recruitment were strongly correlated with water temperature fluctuations at each location. At RK, there was a peak in $D$. vexillum recruitment concurrent with the peak of surface water temperature in both years, supporting the previously recognised influence of water temperature on recruitment patterns (Auker 2006, Osman \& Whitlatch 2007, Auker \& Oviatt 2008, Valentine et al. 2009, Sorte \& Stachowicz 2011). Our findings indicate the recruitment season for $D$. vexillum in central New Zealand is at least 9 mo of the year, considerably longer than comparable northernhemisphere populations ( 3 to $5 \mathrm{mo}$ ). The short period during winter months when no recruitment was detected corresponded to surface water temperatures of approximately $12^{\circ} \mathrm{C}$ or less.

The greater recruitment in Year 2 than Year 1 is most likely a reflection of the change from a weekly to fortnightly sampling at the end of the first reproductive season. The approximate doubling of recruitment at the NN site from Year 1 to 2 is consistent with the doubling of settlement plate exposure time. By contrast, recruitment at RK was fairly consistent between years. We hypothesise that the extensive fouling community immediately adjacent to the experimental arrays at RK led to the settlement plates becoming 'saturated' with recruits during the $2 \mathrm{wk}$ deployment. The marine farm structure at RK contains a considerable surface area of artificial substrata (e.g. steel pontoon, netting, rope) within a relatively condensed area (0.9 hectare), with available surfaces heavily colonised by a range of fouling organisms. In particular, the didemnid ascidian Diplosoma listerianum recruited in very high numbers to the plates at RK, and grew in a sheet-like morphology that often covered much of the available surface. Thus, it is conceivable that the plates became space-limited over the course of each 2 wk deployment.

\section{Onset and cessation of recruitment in relation to seawater temperature}

The onset of Didemnum vexillum recruitment in our study was associated with slightly lower temper- 
atures than previously assumed from other studies, with recruits detected when water temperatures reached $\sim 13^{\circ} \mathrm{C}$ at one of our study sites. In the Gulf of Maine, Valentine et al. (2009) first observed D. vexillum recruits at water temperatures in the range of 14.1 to $19.4^{\circ} \mathrm{C}$. In nearby Narragansett Bay, Rhode Island, recruitment was detected at the considerably higher temperatures of $18.4,19.7$ and $22.5^{\circ} \mathrm{C}$ at 3 different sites (Auker \& Oviatt 2008). It has been suggested that fluctuations in water temperature may limit the onset, but not the decline, of reproduction in ascidians (Millar 1971). In the post-summer period in our study, larvae consistently continued to recruit at temperatures below the onset temperature, with $11.1^{\circ} \mathrm{C}$ being the lowest average temperature where recruits were detected. Larvae in the Gulf of Maine study (Valentine et al. 2009) also continued to recruit at temperatures below the temperature of initial appearance, with recruitment ceasing at temperatures in the range of 9.3 to $11.3^{\circ} \mathrm{C}$, slightly lower than our findings of 11.1 to $11.5^{\circ} \mathrm{C}$.

The length of a species' reproductive season can be affected by preceding periods of unusually cool or warm water temperatures (Cerrano et al. 2000, Coma et al. 2000). Previous studies have indicated that warmer winter temperatures can result in earlier recruitment of Didemnum vexillum as well as overall higher summer abundances (Gittenberger 2007, Valentine et al. 2007a). D. vexillum colonies generally undergo periods of degeneration during the colder winter months, with colonies becoming smaller and more 2-dimensional in morphology. This winter hibernation or dormancy is characterised by a marked decrease in investment in secondary production (i.e. growth and reproduction) over this period (Coma et al. 2000). Valentine et al. (2009) hypothesised that the degree to which colonies degrade in the cool season influences the length of time they require to regenerate, reproduce sexually, and brood and release larvae. They proposed that owing to this, larvae will be released at the end of a developmental period as water temperatures warm, not necessarily when a particular water temperature is reached.

In the Netherlands, unusually warm winter temperatures were thought to be the main reason for a dramatic population increase in Didemnum vexillum in 1998 (Daniel \& Therriault 2007). In 1997, the minimum water temperature was $-2^{\circ} \mathrm{C}$, while in the following year it only dropped to $4^{\circ} \mathrm{C}$. Thus, those authors suggested that colder winter temperatures could have been limiting colony success. A similar result has been documented for Diplosoma listerianum, which fails to recruit at all if mean water temperatures for the preceding winter drop below $\sim 4^{\circ} \mathrm{C}$ (Osman et al. 2010). Based on population observations in the Netherlands and the USA, it has been suggested that $4^{\circ} \mathrm{C}$ may be a critical lower temperature that limits the spread or growth of Didemnum vexillum colonies (Daniel \& Therriault 2007). Extremely high water temperatures have also been shown to reduce the growth of Didemnum vexillum colonies (Gittenberger 2007, McCarthy et al. 2007), thus higher than optimal summer temperatures could also restrict development and reproduction of this species. Sea surface water temperatures in central New Zealand show less annual variation than those documented for the northernhemisphere populations of Didemnum vexillum (ca. 10 to $23^{\circ} \mathrm{C}$ in the present study). It is possible that the reduced seasonal range of temperature, and the lack of associated regulation of reproductive output, is a key factor that explains the extended reproductive season of this species in this study.

It is apparent from our study, and others cited above, that temperature thresholds for recruitment of Didemnum vexillum are inconsistent both within adjacent regions and among different locations globally. Nonetheless, overall patterns in the seasonal relationship between water temperature and recruitment in this species are similar in all cases. Although the duration of the recruitment period varies considerably, seasonal peaks in relation to increased water temperatures are generally consistent among locations. In a similar manner, temperature thresholds for the onset and cessation of $D$. vexillum recruitment vary to some extent between locations globally. However, the general pattern is consistent with higher temperatures required at the onset of recruitment as opposed to the cessation at the end of the reproductive season. In the present study, the variation in the predicted temperature thresholds for this cessation of recruitment (between sites and years) suggests that, while seawater temperature is clearly important, additional factors may also influence recruitment patterns in D. vexillum.

\section{Additional factors driving recruitment variation}

Strong site differences in recruitment between NN and RK were consistent across both years. Considerably lower recruitment at NN is consistent with the fact that source population biomass at that location was considerably less than at RK, and was spread over a wider geographic area. Such findings are in line with expectations regarding the role of propagule pressure in invasion success (Leung \& Mandrak 2007, 
Lockwood et al. 2009), with sites containing source populations of a greater biomass likely to have proportionately greater recruitment success. Additionally, the NN site is in a predominantly estuarine environment with localised salinity variations potentially influencing recruitment success at this site. Colonial ascidian colonies can often tolerate wide fluctuations in salinity; however, they are rarely found in salinities <25 (Millar 1971, Vázquez \& Young 2000, G. Lambert 2005). The NN site is located approximately $1.5 \mathrm{~km}$ from the mouth of a river. Although typical dry weather flows in the river are low $\left(<1 \mathrm{~m}^{3} \mathrm{~s}^{-1}\right)$ and surface salinity adjacent to the NN site is typically 32 to 33, flood flows (mean: $85 \mathrm{~m}^{3} \mathrm{~s}^{-1}$ ) can reduce surface salinity to as low as 20 (B. Forrest unpubl. data). Conceivably, such events could reduce recruitment success at the study site, although they clearly do not prevent it. By contrast, the RK site was unlikely to have been affected by salinity variation, as it has no significant freshwater source nearby.

Fluctuations in other environmental factors such as nutrients, dissolved oxygen and pollutant levels may also influence marine invertebrate reproduction processes (Thorson 1950, Giese 1959, Rivkin 1991), and it can be difficult to solely attribute changes in biological responses to a single variable (Coma et al. 2000, Brockington \& Clarke 2001). For example, seasonal fluctuation of food availability (primarily phytoplankton and suspended organic matter), in conjunction with temperature, are considered crucial to the dynamics of benthic suspension feeders in many temperate coastal communities (Coma et al. 2000). Reproduction investment per zooid is high in species with small zooid size (e.g. didemnids) within the colonial ascidians (Tarjuelo \& Turon 2004) and, as such, seasonal energetic constraints may affect sexual reproduction in this group. Fluctuations in chlorophyll a were found to be correlated with $\mathrm{Di}$ demnum vexillum recruitment patterns at 1 of 3 sites examined by Auker \& Oviatt (2008); nonetheless, in that study, water temperature was shown to be the most important environmental variable. Hence, although a range of factors may be important in the reproductive seasonality of $D$. vexillum, we suggest that seawater temperature provides both a useful and practical indicator for monitoring and assessing recruitment risk in an aquaculture context.

\section{Seasonality of larval development}

The larval development of Didemnum vexillum at RK followed a distinct seasonal pattern that, like recruitment, was correlated with water temperature. There was a marked decrease in egg abundance over the colder winter months, with abundances of the remaining 3 stages also exhibiting smaller fluctuations in line with seasonal changes. While no previous studies have examined the relationship between water temperature and larval production in D. vexillum, our results are supported by similar research on other colonial ascidian species. A strong relationship between water temperature profiles and peak embryo production was found for the brooded larvae of 3 species of Aplidium from the west coast of Scotland (Millar 1958, 1971). Similarly, the colonial ascidian Metandrocarpa taylori showed strong seasonal peaks in the occurrence of brooded larvae on the California coast (Haven 1971). Interestingly, in the present study, there was no extended period of larval absence over the entire sampling period, with mature larvae detected on $90 \%$ of sampling dates at RK. By contrast, recruits on settlement plates at RK were detected on only $80 \%$ of sampling occasions, with a distinct and continuous absence over the winter period. As such, it appears that despite the potential for recruitment being indicated by the presence of mature larvae, recruits are not being detected in the field.

\section{Implications for shellfish aquaculture risk management}

Patterns of seasonal reproduction in Didemnum vexillum illustrated here have implications for the commercial culture of green-lipped mussels in our study region. Accumulated biofouling on mussel lines often presents a serious operational challenge to farm managers and can negatively affect farm productivity (Gretchis 2005, McKindsey et al. 2007, Daigle \& Herbinger 2009, Davis \& Davis 2010). Patterns of biomass accumulation for $D$. vexillum in this region closely follow the recruitment patterns described in the present study (L. Fletcher unpubl. data); following settlement, individual recruits can undergo rapid expansion through asexual budding of zooids to form substantial colonies. Population biomass of this species is highest over the summer period, with colonies typically undergoing a winter regression, as observed in other locations globally (e.g. Valentine et al. 2007a). Periods of increased recruitment and growth of $D$. vexillum will influence the level of connectivity and potential spread of established populations, with higher biomass leading to increased propagule pressure. Information on 
reproductive seasonality and colony development of $D$. vexillum is therefore essential for effective timing of mitigation techniques, as well as for developing vector management plans (e.g. movement of boats and seed stock) to prevent secondary spread from infected locations.

Both the settlement plate and colony tissue section sampling methods used in the present study provided valuable information on the reproductive seasonality of Didemnum vexillum. Both methods could be easily applied in an aquaculture industry setting; however, the preferred method would depend on whether managers were interested in solely detecting recruitment potential or documenting the magnitude involved. The possibility of detection issues with the settlement plate method, with perhaps very low levels of recruitment being missed during the winter months, means tissue section analysis may provide more reliable results for less effort, or at least a more conservative estimate of recruitment potential. Although tissue section analysis would not reliably reflect the magnitude of recruitment during the reproductive season, our cross-correlation analysis showed a 2 to $4 \mathrm{wk}$ lag in peaks in recruitment levels when compared to MI values. As such, tissue analysis could provide an early warning of the onset of spawning at the beginning of the season.

Monitoring using either method would provide relatively simple means for the shellfish industry to track the risk of their seed-stock and crops becoming infected by Didemnum vexillum. Such knowledge would enable the industry to mitigate the adverse effects of $D$. vexillum fouling through management of farm operations around seasonal windows of risk. In our study area, which is New Zealand's most important region for mussel culture, shellfish crops are vulnerable to $D$. vexillum infestation for at least 9 mo of the year, and probably longer based on the results of tissue section analysis. This duration is considerably longer than was previously believed for the region, meaning that opportunities for management are less than once envisaged. However, the same management principles can be applied to other locations and other fouling species. For example, future mussel industry plans in New Zealand involve holding hatchery-reared spat in the sea for short-term grow-out (3 to $4 \mathrm{mo}$ ) before distribution to different growing regions nationally. Knowledge of seasonal fouling recruitment windows could be used to minimise risk to the spat, which is a relatively vulnerable stage in the industry production chain. Furthermore, by reducing fouling risk during short-term grow-out, there will be a concomitant reduction in the likeli- hood that high-risk species will be inadvertently spread among growing regions as a result of interregional spat transfers.

Acknowledgements. We are grateful to Gabrielle Lowe, Grant Hopkins, Richard Piola, Kirsty Smith and Eric Goodwin for their assistance with various aspects of the experiments and data analysis, as well as 4 anonymous reviewers whose helpful comments improved this manuscript. Sincere thanks are also expressed to New Zealand King Salmon Ltd, in particular staff at the Ruakaka Bay farm, who provided considerable logistic support for this project, as well as staff at the Port Nelson gatehouse for access to the super yacht berth. This work was funded by the New Zealand Ministry of Business, Innovation and Employment under Contract PROJ-13785-PPS-CAW (Adding Value to New Zealand's Cultured Shellfish Industry: Maximising Profitability, Minimising Risk). L.M.F. was funded through a joint Cawthron Institute and New Zealand Tertiary Education Commission 'Bright Futures Enterprise PhD Scholarship'.

\section{LITERATURE CITED}

Abramoff MD, Magalhaes PJ, Ram SJ (2004) Image processing with ImageJ. Biophotonics Int 11:36-42

Adams CM, Shumway SE, Whitlatch RB, Getchis T (2011) Biofouling in marine molluscan shellfish aquaculture: a survey assess the business and economic implications of mitigation. J World Aquacult Soc 42:242-252

Anderson MJ (2001) A new method for non-parametric analysis of variance. Austral Ecol 26:32-46

Anderson MJ, Gorley RN (2007) PERMANOVA+ for PRIMER: guide to software and statistical methods. PRIMER-E, Plymouth

Auker LA (2006) An invasive tunicate, Didemnum sp., in Narragansett Bay, Rhode Island. MSc thesis, University of Rhode Island, Kingston

Auker LA, Oviatt CA (2008) Factors influencing the recruitment and abundance of Didemnum in Narragansett Bay, Rhode Island. ICES J Mar Sci 65:765-769

> Bates WR (2005) Environmental factors affecting reproduction and development in ascidians and other prochordates. Can J Zool 83:51-61

Blum JC, Chang AL, Lijesthröm M, Schenk ME, Steinberg MK, Ruiz GM (2007) The non-native solitary ascidian Ciona intestinalis (L.) depresses species richness. J Exp Mar Biol Ecol 342:5-14

Brockington S, Clarke A (2001) The relative influence of temperature and food on the metabolism of a marine invertebrate. J Exp Mar Biol Ecol 258:87-99

> Cerrano C, Bavestrello G, Bianchi CN, Cattaneo-vietti R and others (2000) A catastrophic mass-mortality episode of gorgonians and other organisms in the Ligurian Sea (North-western Mediterranean), summer 1999. Ecol Lett 3:284-293

Clarke KR (1993) Non-parametric multivariate analyses of change in community structure. Aust J Ecol 18:117-143

Clarke KR, Gorley RN (2006) PRIMER v6.1.6: user manual/ tutorial. PRIMER-E, Plymouth

Coma R, Ribes M, Gili JM, Zabala M (2000) Seasonality in coastal benthic ecosystems. Trends Ecol Evol 15:448-453

Coutts ADM, Forrest BM (2007) Development and application of tools for incursion response: lessons learned from 
the management of the fouling pest Didemnum vexillum. J Exp Mar Biol Ecol 342:154-162

Daigle RM, Herbinger CM (2009) Ecological interactions between the vase tunicate (Ciona intestinalis) and the farmed blue mussel (Mytilus edulis) in Nova Scotia, Canada. Aquat Invasions 4:177-187

Daniel KS, Therriault TW (2007) Biological synopsis of the invasive tunicate Didemnum sp. Can Manuscr Rep Fish Aquat Sci 2788. Fisheries and Oceans Canada, Ottawa

$>$ Davis MH, Davis ME (2010) The impact of the ascidian Styela clava Herdman on shellfish farming in the Bassin de Thau, France. J Appl Ichthyol 26(Suppl S2):12-18

Dealteris JT, Kilpatrick BD, Rheault RB (2004) A comparative evaluation of the habitat value of shellfish aquaculture gear, submerged aquatic vegetation and a nonvegetated seabed. J Shellfish Res 23:867-874

Fitridge I, Dempster T, Guenther J, de Nys R (2012) The impact and control of biofouling in marine aquaculture: a review. Biofouling 28:649-669

Giese AC (1959) Comparative physiology: annual reproductive cycles of marine invertebrates. Annu Rev Physiol 21: $547-576$

> Gittenberger A (2007) Recent population expansions of nonnative ascidians in the Netherlands. J Exp Mar Biol Ecol 342:122-126

Goodbody I (1961) Continuous breeding in three species of tropical ascidians. Proc Zool Soc Lond 136:403-409

Gretchis TS (2005) What's putting some aquaculturists in a 'foul' mood? Wrack Lines 5:8-10

> Haven ND (1971) Temporal patterns of sexual and asexual reproduction in the colonial ascidian Metandrocarpa taylori Huntsman. Biol Bull (Woods Hole) 140:400-415

$>$ Hurlbert SH (1984) Pseudoreplication and the design of ecological field experiments. Ecol Monogr 54:187-211

Keough MJ, Downes BJ (1982) Recruitment of marine invertebrates: the role of active larval choices and early mortality. Oecologia 54:348-352

$>$ Kott P (2002) A complex didemnid ascidian from Whangamata, New Zealand. J Mar Biol Assoc UK 82:625-628

> Lambert CC (2005) Historical introduction, overview, and reproductive biology of the protochordates. Can J Zool 83:1-7

Lambert G (2005) Ecology and natural history of the protochordates. Can J Zool 83:34-50

> Lambert G (2007) Invasive sea squirts: a growing global problem. J Exp Mar Biol Ecol 342:3-4

> Lambert G (2009) Adventures of a sea squirt sleuth: unravelling the identity of Didemnum vexillum, a global ascidian invader. Aquat Invasions 4:5-28

> Leung B, Mandrak NE (2007) The risk of establishment of aquatic invasive species: joining invasibility and propagule pressure. Proc R Soc Lond B Biol Sci 274:2603-2609

$>$ Lockwood JL, Cassey P, Blackburn TM (2009) The more you introduce the more you get: the role of colonization pressure and propagule pressure in invasion ecology. Divers Distrib 15:904-910

McCarthy A, Osman RW, Whitlatch RB (2007) Effects of temperature on growth rates of colonial ascidians: a comparison of Didemnum sp. to Botryllus schlosseri and Botrylloides violaceus. J Exp Mar Biol Ecol 342:172-174

> McKindsey CW, Landry T, O'Beirn FX, Davies IM (2007) Bivalve aquaculture and exotic species: a review of ecological considerations and management issues. J Shellfish Res 26:281-294

Millar RH (1958) The breeding season of some littoral ascid- ians in Scottish waters. J Mar Biol Assoc UK 37:649-652

Millar RH (1971) The biology of ascidians. Adv Mar Biol 9: $1-100$

> Osman RW, Whitlatch RB (2007) Variation in the ability of Didemnum sp. to invade established communities. J Exp Mar Biol Ecol 342:40-53

> Osman RW, Munguia P, Whitlatch RB, Zajac RN, hamilton $\mathrm{J}$ (2010) Thresholds and multiple community states in marine fouling communities: integrated natural history with management strategies. Mar Ecol Prog Ser 413: $277-289$

Pannell A, Coutts ADM (2007) Treatment methods used to manage Didemnum vexillum in New Zealand. Report prepared for Biosecurity New Zealand, Marine Farming Association Inc, Blenheim

Perez-Portela R, Palacin C, Duran S, Turon X (2007) Biological traits of three closely related species of Pycnoclavella (Ascidiacea) in the Western Mediterranean. Mar Biol 152:1031-1038

R Development Core Team (2011) R: a language and environment for statistical computing. R Foundation for Statistical Computing, Vienna. www.R-project.org

Ramsay A, Davidson J, Landry T, Arsenault G (2008) Process of invasiveness among exotic tunicates in Prince Edward Island, Canada. Biol Invasions 10:1311-1316

Ramsay A, Davidson J, Bourque D, Stryhn H (2009) Recruitment patterns and population development of the invasive ascidian Ciona intestinalis in Prince Edward Island, Canada. Aquat Invasions 4:169-176

Rivkin RB (1991) Seasonal patterns of planktonic production in McMurdo Sound, Antarctica. Am Zool 31:5-16

> Sorte CJB, Stachowicz JJ (2011) Patterns and processes of compositional change in a California epibenthic community. Mar Ecol Prog Ser 435:63-74

Stefaniak L, Zhang H, Gittenberger A, Smith K, Holsinger K, Lin S, Whitlatch R (2012) Determining the native region of the putatively invasive ascidian Didemnum vexillum Kott, 2002. J Exp Mar Biol Ecol 422-423:64-71

Stoner DS (1990) Recruitment of a tropical colonial ascidian: relative importance of pre-settlement vs. post-settlement processes. Ecology 71:1682-1690

> Tarjuelo I, Turon X (2004) Resource allocation in ascidians: reproductive investment vs. other life-history traits. Invertebr Biol 123:168-180

Thorson G (1950) Reproductive and larval ecology of marine bottom invertebrates. Biol Rev Camb Philos Soc 25:1-45

Turon X (1988) The ascidians of Tossa de Mar (NE Spain) 2. Biological cycles of the colonial species. Cah Biol Mar 29: 407-418

Turon X (1992) Periods of non-feeding in Polysyncraton lacazei (Ascidiacea: Didemnidae): a rejuvenative process? Mar Biol 112:647-655

USNO (US Naval Observatory) (2012) Duration of daylight/ darkness table. USNO, Astronomical Application Department, Washiongton, DC. Available at http://aa.usno. navy.mil/data/docs/Dur_OneYear.php (accessed 12 Mar 2012)

> Valentine PC, Carman MR, Blackwood DS, Heffron EJ (2007a) Ecological observations on the colonial ascidian Didemnum sp. in a New England tide pool habitat. J Exp Mar Biol Ecol 342:109-121

Valentine PC, Collie JS, Reid RN, Asch RG, Guida VG, Blackwood DS (2007b) The occurrence of the colonial ascidian Didemnum sp. on Georges Bank gravel habitat-ecological observations and potential effects on 
groundfish and scallop fisheries. J Exp Mar Biol Ecol 342: 179-181

Valentine PC, Carman MR, Dijkstra J, Blackwood DS (2009) Larval recruitment of the invasive colonial ascidian Didemnum vexillum, seasonal water temperatures in New England coastal and offshore waters, and implications for the spread of the species. Aquat Invasions 4: 153-168

Vance T, Lauterbach L, Lenz M, Wahl M, Sanderson RA, Thomason JC (2009) Rapid invasion and ecological interactions of Diplosoma listerianum in the North Sea, UK. Mar Biodivers Rec 2:1-5

Editorial responsibility: Tim Dempster, Trondheim, Norway
Van Duyl FC, Bak RPM, Sybesma J (1981) The ecology of the tropical compound ascidian Trididemnum solidum. I. Reproductive strategy and larval behavior. Mar Ecol Prog Ser 6:35-42

Vázquez E, Young CM (2000) Effects of low salinity on metamorphosis in estuarine colonial ascidians. Invertebr Biol 119:433-444

Yoshida M (1952) Some observations on the maturation of the sea urchin, Diadema setosum. Annot Zool Jpn 25:265-271

Zuur AF, Ieno EN, Walker N, Saveliev AA, Smith GM (2009) Mixed effects models and extensions in ecology with R. Springer, New York, NY

Submitted: August 22, 2012; Accepted: February 7, 2013 Proofs received from author(s): March 25, 2013 